\title{
ホウ素含有アパタイト単結晶のフラックス合成と結晶構造
}

\author{
伊藤敦夫・青木秀希*·赤尾勝*.三浦直樹* · 大塚良平 ·堤 貞夫** \\ 早稲田大学理工学部資源工学科, 160 東京都新宿区大久保 3-4-1 \\ * 東京医科歯科大学医用器材研究所無機材料部門, 101 東京都千代田区神田駿河台 2-3-10 \\ ** 早稲田大学教育学部理学科地学専修, 160 東京都新宿区西早稲田 1-6-1
}

\section{Flux Growth and Crystal Structure of Boron-Containing Apatite}

Atsuo ITO, Hideki AOKI*, Masaru AKAO*, Naoki MIURA*, Ryohei OTSUKA and Sadao TSUTSUMI**

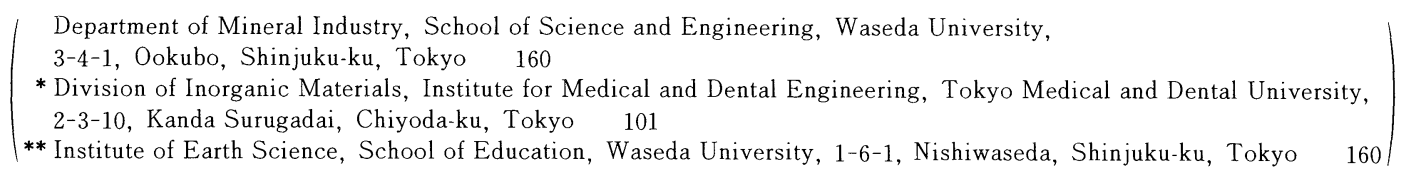

Single crystals of boron-containing apatite (BAP) were growen by standard flux growth technique with excess $\mathrm{B}_{2} \mathrm{O}_{3}$ as flux. A mixture with the composition $35 \mathrm{CaO}-5 \mathrm{P}_{2} \mathrm{O}_{5}-60 \mathrm{~B}_{2} \mathrm{O}_{3}\left(\right.$ wt \%) was heated at $1200^{\circ} \mathrm{C}$ for 10 hours and then cooled at a rate of $8.3^{\circ} \mathrm{C} / \mathrm{h}$. Hexagonal prismatic crystals $(0.3 \mathrm{~mm} \times 0.3 \mathrm{~mm} \times 11 \mathrm{~mm})$ were obtained. The chemical composition of $B A P$ 's was expressed as a solid solution in the system $C a_{10}\left(P_{4}\right)_{5} B O_{4}-C a_{9.5}\left(P_{4}\right)_{6} B O_{2}$. BAP with the composition $C a_{9.64}$ $\left(P_{5.73} B_{0.27} O_{24}\right)\left(B O_{2}\right)_{0.73}$ is trigonal, space group $P \overline{3}$ with $a=9.456(1), c=6.905(1) \AA$ and $Z=1$. The structure was refined to $R=0.050$ and $R_{w}=0.044$ for 1257 independent reflections. The structure is apatitic in character but the $B$ atom at $(001 / 2$ forms a linear $O-B-O$ group.

[Received October 14, 1987 ; Accepted December 15, 1987]

Key-words: Flux growth, Boron oxide, Boron-containing apatite, Chemical composition, Crystal structure, $\mathrm{BO}_{2}$ group

\section{1. 緒 言}

アパタイトは生体材料, 蛍光体, 吸着材等に使用され ている．その単結晶は水熱法又はフラックス法で合成さ れる.フラックス法による合成は, (1) $\mathrm{CaCl}_{2}, \mathrm{CaF}_{2}$ な どのハライド系フラックスを用いるもの, (2) ホウ酸塩 系のフラックスを用いるもの, (3) $\mathrm{Ca}(\mathrm{OH})_{2}$ を用いた水 熱フラックス法の三つに分類できる. 例えば $\mathrm{Ca}_{10}\left(\mathrm{PO}_{4}\right)$ ${ }_{6} \mathrm{~F}_{2}{ }^{1)}, \mathrm{Ca}_{10}\left(\mathrm{PO}_{4}\right)_{6} \mathrm{Cl}_{2}{ }^{1)}, \mathrm{Sr}_{10}\left(\mathrm{PO}_{4}\right)_{6} \mathrm{Cl}_{2}{ }^{2)}, \mathrm{Cd}_{10}\left(\mathrm{PO}_{4}\right)$ ${ }_{6} \mathrm{I}_{2}{ }^{3)}, \mathrm{Cd}_{10}\left(\mathrm{PO}_{4}\right)_{6} \mathrm{Br}_{2}{ }^{3)}, \mathrm{Cd}_{10}\left(\mathrm{AsO}_{4}\right)_{6} \mathrm{Br}_{2}{ }^{3)}, \mathrm{Cd}_{10}\left(\mathrm{VO}_{4}\right)$ ${ }_{6} \mathrm{Br}_{2}{ }^{3)}, \mathrm{Cd}_{10}\left(\mathrm{PO}_{4}\right){ }_{6} \mathrm{Cl}_{2}{ }^{4)}$ 単結晶が(1) の方法で, $\mathrm{Ca}_{9+\mathrm{y}} \mathrm{Na}_{x}\left(\mathrm{PO}_{4}\right)_{6} \mathrm{~B}_{x+2 y} \mathrm{O}_{2}(9+y+x<10, x+2 y<1)^{5)}$, $\mathrm{Sr}_{9+y} \mathrm{Na}_{x}\left(\mathrm{PO}_{4}\right)_{6} \mathrm{~B}_{x+2 y} \mathrm{O}_{2}(9+y+x<10, x+2 y<1)^{5,66}$ 単結晶が(2)の方法で, $\mathrm{Ca}_{10}\left(\mathrm{PO}_{4}\right)_{6}(\mathrm{OH})_{2}$ 単結晶7),8)が(3) の方法で合成されている，アパタイトは単結晶に成長さ せにくい結晶であり， $\mathrm{Ca}_{10}\left(\mathrm{PO}_{4}\right)_{6} \mathrm{~F}_{2}{ }^{1)}, \mathrm{Ca}_{10}\left(\mathrm{PO}_{4}\right)_{6} \mathrm{Cl}_{2}$ で3 5 $\mathrm{mm}^{1)}, \mathrm{Ca}_{10}\left(\mathrm{PO}_{4}\right)_{6}(\mathrm{OH})_{2}$ で 4 8 $\mathrm{mm}^{7), 8)}$ の結晶 が得られているほかは, すべて結晶構造解析用の試料で ある。

以上のフラックス合成法のうち, $\mathrm{Na}_{2} \mathrm{~B}_{4} \mathrm{O}_{7} \cdot 10 \mathrm{H}_{2} \mathrm{O}$ の ようなホウ酸塩系のフラックスを用いた報告は少ない. また $\mathrm{CaO}-\mathrm{P}_{2} \mathrm{O}_{5}-\mathrm{B}_{2} \mathrm{O}_{3}$ 系にホウ素含有アパタイト(以下 BAP と略) が存在するとされているが9,10), BAP の化 学組成, $\mathrm{B}$ の固溶範囲, 及び $\mathrm{B}$ の配位は明確にされて いない. 本研究では $\mathrm{CaO}-\mathrm{P}_{2} \mathrm{O}_{5}-\mathrm{B}_{2} \mathrm{O}_{3}$ 系からフラックス
徐冷法で BAP の単結晶を合成し, BAP の化学分析と 結晶構造解析を行った。

\section{1 出発物質}

合成の出発物質には水酸アパタイト $\mathrm{Ca}_{10}\left(\mathrm{PO}_{4}\right)_{6}$ $(\mathrm{OH})_{2}$ (以下 $\mathrm{HAP}$ と略) , $\mathrm{B}_{2} \mathrm{O}_{3}, \mathrm{CaO}$ の混合物を用い た. HAP は特級 $\mathrm{Ca}(\mathrm{OH})_{2}$ の $0.5 \mathrm{M}$ 懸濁液中に特級 $\mathrm{H}_{3} \mathrm{PO}_{4}$ の $0.3 \mathrm{M}$ 溶液を滴下して合成した。化学分析の 結果この $\mathrm{HAP}$ の $\mathrm{Ca} / \mathrm{P}$ モル比は 1.69 であった. $\mathrm{B}_{2} \mathrm{O}_{3}$ は特級試薬を用いた。 $\mathrm{B}_{2} \mathrm{O}_{3}$ は一部水和して $\mathrm{HBO}_{2}$ が生 成していたので熱重量分析により水分量を定量して補正 した. $\mathrm{CaO}$ はアルカリ分析用 $\mathrm{CaCO}_{3}$ を $950^{\circ} \mathrm{C}, 3$ 時間 焼成して得た。

\section{2 相関係}

$\mathrm{HAP}, \mathrm{CaO}, \mathrm{B}_{2} \mathrm{O}_{3}$ を科量しアルミナ乳鉢中で 10 分 間乾式混合した。この混合物約 $1 \mathrm{~g}$ を $15 \mathrm{ml}$ 白金るつぼ にかるく詰め, 縦型炉を用いて空気中で加熱した。 $1150^{\circ} \mathrm{C}$ 以上では試料の蒸発が著しくなるため, 加熱は この温度より低い温度範囲で行った. 加熱温度を $900^{\circ}$, $950^{\circ}, 1000^{\circ}, 1050^{\circ}, 1100^{\circ}$ 及び $1130^{\circ} \mathrm{C}$ とし, それぞれ の温度で 1 48 時間加熱して相関係を調べた. 加熱後合 成物は空気中で急冷し, 相同定は粉末 X 線回折法と偏 光顕微鏡観察により行った. 
Table 1. Preparation conditions of BAP single crystals.

\begin{tabular}{|c|c|c|c|c|c|c|c|}
\hline & \multicolumn{4}{|c|}{ Starting mixture } & \multirow{2}{*}{$\begin{array}{c}\text { Keep } \\
\text { temperature } \\
\left({ }^{\circ} \mathrm{C}\right)\end{array}$} & \multirow{2}{*}{$\begin{array}{l}\text { Keep } \\
\text { time } \\
(\mathrm{h})\end{array}$} & \multirow{2}{*}{$\begin{array}{l}\text { Cooling } \\
\text { rate } \\
\left({ }^{\circ} \mathrm{C} / \mathrm{h}\right)\end{array}$} \\
\hline & \multicolumn{3}{|c|}{$\begin{array}{c}\mathrm{CaO}: \mathrm{P}_{2} \mathrm{O}_{5}: \mathrm{B}_{2} \mathrm{O}_{3} \\
(\mathrm{wt} \%)\end{array}$} & \multirow{2}{*}{$\begin{array}{c}\text { Weight } \\
\text { (g) } \\
250\end{array}$} & & & \\
\hline BAPI & 38 & 10 & 52 & & 1200 & 3 & 80.0 \\
\hline BAP2 & 38 & 10 & 52 & 250 & 1200 & 4 & 26.6 \\
\hline BAP 3 & 38 & 10 & 52 & 250 & 1200 & 10 & 8.3 \\
\hline BAP 4 & 35 & 5 & 60 & 250 & 1200 & 10 & 8.3 \\
\hline
\end{tabular}

\section{3 単結晶育成}

$200 \mathrm{ml}$ 白金るつぼと箱型炉を用い，フラックス徐冷 法で結晶育成を行った．合成条件を表 1 に示す．出発物 質は液相線が $1130^{\circ} \mathrm{C}$ 付近にあるものを用いた。 $250 \mathrm{~g}$ の出発物質を $1200^{\circ} \mathrm{C}$ に $3 \sim 10$ 時間保持し, $80^{\circ}$ $8.3^{\circ} \mathrm{C} / \mathrm{h}\left(1200^{\circ} \sim 400^{\circ} \mathrm{C}\right)$ の徐冷速度で冷却し, その後 炉内で室温まで放冷した。合成物は $5 \%$ 酢酸中で加熱 し, フラックスを溶解, 除却した。

\section{4 化学組成}

BAP の化学分析を Ca は EDTA 逆滴定法 ${ }^{11)}$ (NN 指 示薬), $\mathrm{P}$ はモリブデンブルー比色法 ${ }^{12)}$, $\mathrm{B}$ はカルミン 酸比色法 ${ }^{13)}$ で行った。

\section{5 結晶構造解析}

表 1 の BAP 2 の条件で得られた， $0.40 \times 0.05 \times 0.05$ $\mathrm{mm}^{3}$ の六角柱状結晶を用いて X 線結晶構造解析を行っ た.ワイセンベルグ写真法で空間群を決定した. 回折強 度の測定は, フィリップス製 4 軸型自動回折計 PW 1100 を用い, 黒鉛で単色化した Mo $K \alpha$ 線, $\omega-2 \theta$ スキャ ン, 走查速度 $\omega=4^{\circ} / \mathrm{min}, 2 \theta<80^{\circ}$ で行った. $\left|F_{\mathrm{o}}\right|>3$ $\sigma\left|F_{\mathrm{o}}\right|$ を満たす 1257 個の独立な強度を測定し，Lp因 子の補正を行った. 中性原子の原子散乱因子, 及び異常 分散項は International Tables for X-ray Crystallography, Vol. $4^{14)}$ の值を用いた。 反射デー夕に対する重 みには $W=1 /\left(A+B\left|F_{\mathrm{o}}\right|+C\left|F_{\mathrm{o}}\right|^{2}+D\left|F_{\mathrm{o}}\right|^{3}\right)$ を用いた. パラメーター $A, B, C, D$ は, $W\left(\left|F_{\mathrm{o}}\right|-\left|F_{\mathrm{c}}\right|\right) 2$ が $\left|F_{\mathrm{o}}\right|$ の大きさに対して一様に分布するように選び，精 密化の最終段階では $A=3.3949, B=-0.12635, C=$ $0.001717, D=-0.000005$ であった。

BAP の粉末 X 線回折パターンはHAP とよく似てい る. 格子定数は粉末 $\mathrm{X}$ 線回折法 $(\mathrm{Cu} K \alpha$ 線 $)$ で, $\mathrm{Si}$ を 内部標準とし, $2 \theta<50^{\circ}$ の範囲で 11 本の回折線を精密 に測定し，プログラム RLC-3 ${ }^{15)}$ を用いて精密化した.

\section{3. 結 果}

\section{1 相関係}

$\mathrm{CaO}-\mathrm{P}_{2} \mathrm{O}_{5}-\mathrm{B}_{2} \mathrm{O}_{3}$ 系の平衡状態図は $900^{\circ} \mathrm{C}$ 等温断面が Ramamoorthy と Rockett ${ }^{10)}$ によって報告されている. しかし BAP と液相の 2 相領域は今まで報告されていな かった. 本研究では, BAP は $900^{\circ}, 950^{\circ}, 1000^{\circ}, 1050^{\circ}$,



Fig. 1. Phase relations in $\mathrm{CaO}-\mathrm{P}_{2} \mathrm{O}_{5}-\mathrm{B}_{2} \mathrm{O}_{3}$ system at $1130^{\circ} \mathrm{C}$. Each sample was heated at this temperature for 5h. BAP indicates boron-containing apatite; $\mathrm{C}_{3} \mathrm{P}$, $\mathrm{Ca}_{3}\left(\mathrm{PO}_{4}\right)_{2} ; \mathrm{CB}, \mathrm{CaB}_{2} \mathrm{O}_{4}$.

$1100^{\circ}$ 及び $1130^{\circ} \mathrm{C}$ の各温度で生成し, BAP と液相の 2 相領域も $1000^{\circ} \mathrm{C}$ 以上で存在することが粉末 X 線回折法 と偏光顕微鏡観察からわかった。図 1 に $1130^{\circ} \mathrm{C}$ での BAP と液相の 2 相領域を示す. BAP と液相の 2 相領 域は図1の $\triangle \mathrm{abc}$ 点の内部にある. $\mathrm{a}$ 点 $(\mathrm{CaO} 56.84$, $\left.\mathrm{P}_{2} \mathrm{O}_{5} 43.16 \mathrm{wt} \%\right)$ は HAP から水を除いた組成点で才 キシアパタイト $\left[\mathrm{Ca}_{10}\left(\mathrm{PO}_{4}\right)_{6} \mathrm{O}\right]$ の組成に相当する.b 点, c 点はそれぞれ $\left(\mathrm{CaO} 43, \mathrm{~B}_{2} \mathrm{O}_{3} 57 \mathrm{wt} \%\right),(\mathrm{CaO} 30$, $\mathrm{B}_{2} \mathrm{O}_{3} 70 \mathrm{wt} \%$ ) である. ac より $\mathrm{Ca}$ が少ない領域では $\mathrm{BAP} と \beta-\mathrm{Ca}_{3}\left(\mathrm{PO}_{4}\right)_{2}, \mathrm{ab}$ より $\mathrm{Ca}$ が多い領域では $\mathrm{BAP}$ と $\mathrm{CaB}_{2} \mathrm{O}_{4}$ が生成した。液相線は $1130^{\circ} \mathrm{C}$ では $\mathrm{P}_{2} \mathrm{O}_{5} \fallingdotseq 10 \mathrm{wt} \%$ に存在していた. 単結晶の育成にはd 点 (BAP 1, 2, 3), e 点 (BAP 4) の組成の出発物質を 用いた。

\section{2 単結晶育成}

合成された BAP 結晶は BAP 1, 2,3,4（表 1) とも 無色透明, $c$ 軸方向に伸長した六角柱状結晶で, $c$ 軸方 向の長さは最大 $11 \mathrm{~mm}$, 太さは最大 $0.3 \mathrm{~mm}$ であった (図 2). 結晶はフラックス中だけでなくるつぼ内壁面及 びるつぼ外壁面にも生成した。るつぼ内壁面に生成した 結晶は針状のアパタイトであり，特に壁面の頂部に生成 したアパタイトは先端に球状付着物を有するものもあっ た.るつぼ外壁面に生成した結晶は $\beta-\mathrm{Ca}_{3}\left(\mathrm{PO}_{4}\right)_{2}$ であっ た.

\section{3 化学組成}

BAP の分析結果と HAP の理論組成を表 2 に示す. 化学分析の結果 BAP $1,2,3,4$ とも $\mathrm{B}$ が $\mathrm{B}_{2} \mathrm{O}_{3}$ として 


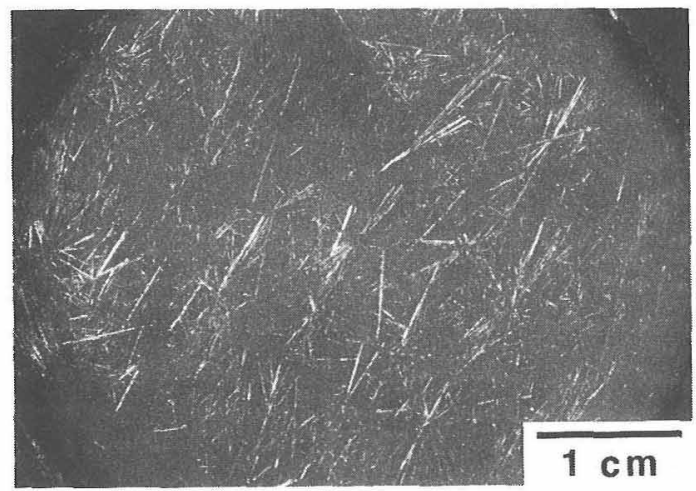

Fig. 2. Single crystals of BAP. $250 \mathrm{~g}$ of starting mixture with composition $35 \mathrm{CaO}-5 \mathrm{P}_{2} \mathrm{O}_{5}-60 \mathrm{~B}_{2} \mathrm{O}_{3}$ (in wt \% ) was heated at $1200^{\circ} \mathrm{C}$ for $10 \mathrm{~h}$ and then cooled at a rate of $8.3^{\circ} \mathrm{C} / \mathrm{h}$.

Table 2. Chemical compositions (wt \%) and $\mathrm{Ca} / \mathrm{P}$ molar ratios for BAP compared with the theoretical values for HAP.

\begin{tabular}{lrrrrr}
\hline \hline & BAPI & BAP2 & BAP3 & BAP4 & HAP \\
\hline $\mathrm{CaO}$ & 54.90 & 54.73 & 54.94 & 54.67 & 55.82 \\
$\mathrm{P}_{2} \mathrm{O}_{5}$ & 41.01 & 41.15 & 41.44 & 41.58 & 42.39 \\
$\mathrm{~B}_{2} \mathrm{O}_{3}$ & 3.83 & 3.83 & 3.90 & 3.80 & - \\
$\mathrm{H}_{2} \mathrm{O}$ & - & - & - & - & 1.79 \\
\hline Total & 99.74 & 99.71 & 100.28 & 100.05 & 100.00 \\
$\mathrm{Ca} / \mathrm{P}$ & 1.69 & 1.68 & 1.67 & 1.66 & 1.67 \\
\hline \hline
\end{tabular}

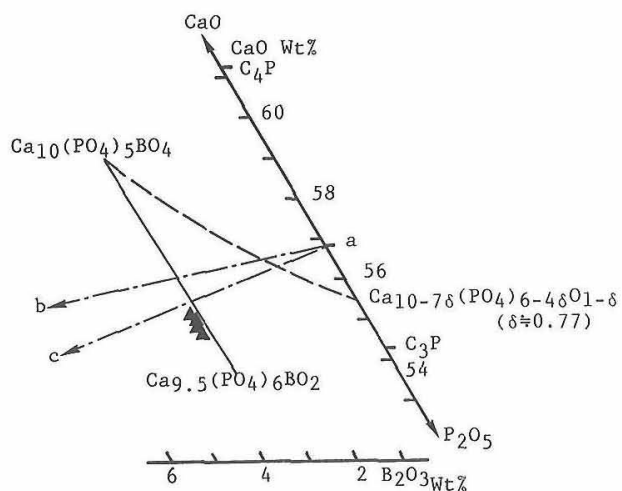

a $\mathrm{Ca} 056.84 \mathrm{P}_{2} \mathrm{O}_{5} 43.16 \mathrm{Wt} \%$

b $\mathrm{CaO} 43 \mathrm{~B}_{2} \mathrm{O}_{3} 57$ Wt\%

c $\mathrm{CaO} 30 \quad \mathrm{~B}_{2} \mathrm{O}_{3} 70$ Wt\%

Fig. 3. Triangular diagram showing the composition of BAP. Dashed curve is from Ramamoorthy and Rockett $(1974)^{10)}$, solid triangles showing data from the present study.

3. 80 〜 3.90 wt \% 含まれていること, $\mathrm{CaO}\left\llcorner\mathrm{P}_{2} \mathrm{O}_{5}\right.$ の含

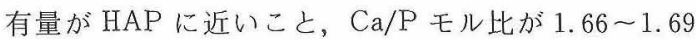
であることがわかった。図3に分析結果の $\mathrm{CaO}-\mathrm{P}_{2} \mathrm{O}_{5}-\mathrm{B}_{2} \mathrm{O}_{3}$ 系三角図へのプロットを示す。破線は Ramamoorthy とRockett ${ }^{10)}$ が報告した BAP の組成で ある、1点鎖線は図 1 における, “BAP+液相”領域境
界線 $\mathrm{ab}, \mathrm{ac}$ の位置を表したものである，この研究で合 成した BAP の組成は $\mathrm{Ca}_{9.5}\left(\mathrm{PO}_{4}\right)_{6} \mathrm{BO}_{2}-\mathrm{Ca}_{10}\left(\mathrm{PO}_{4}\right)_{5} \mathrm{BO}_{4}$ 固溶体の組成に一致した。

\section{4 結晶構造解析}

$c$ 軸回転の高次層ワイセンベルグ写真には 6 回対称は 存在せず，3回対称のみ存在した， $a$ 軸回転の 0 層ワイ センベルグ写真には $a^{*}$ 軸をはさむ班点の強度に鏡面対 称がないことから，BAPのラウ工群は可であることが わかった，消滅則も認められず，BAP の空間群は通常 のアパタイトの空間群 $\left(P 6_{3} / m\right)$ とは異なり, $P \overline{3}$ 又 はP $P$ であることがわかった，格子定数は $a=9.456$

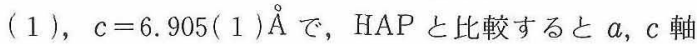
とも約 $0.4 \%$ 伸長していた。結晶学的デー夕を表 3 に 示す。空間群 $P \overline{3}$ を採用し，パターソン関数を解いて $\mathrm{Ca}$ 上 $\mathrm{P}$ の原子座標を決めた。 $\mathrm{Ca}, \mathrm{P}, \mathrm{O}$ の原子坐標之 非等方性温度因子を精密化 (プログラム LINUS ${ }^{16)}$ ) し た. 差フーリエ図の $(001 / 2)$ に高いピークが見つかっ たのでこれを B 原子とした，B は2個の O( 4 ) (HAP の $\mathrm{OH}$ 基の $\mathrm{O}$ に相当）に直線的に配位されて $\mathrm{BO}_{2}$ 基を 形成していた。

Table 3. Crystal data of the BAP. Crystal data

$$
\begin{aligned}
& \text { Ca. } 93\left(P_{5} .84 O_{24}\right) B_{0} 0.830_{1} .79 \\
& \text { F.W. } 1000.45 \\
& Z=1 \\
& a=9.456(1), \quad c=6.905(1) \quad(\AA) \\
& \text { Space group } \quad P \overline{3} \\
& \text { Dealc. }=3.11 \quad\left(\mathrm{~g} / \mathrm{cm}^{3}\right)
\end{aligned}
$$

\begin{tabular}{|c|c|c|c|c|c|c|c|}
\hline & Population & $x$ & $y$ & 2 & & & \\
\hline Ca(la) & $0.963(7)$ & $1 / 3$ & $2 / 3$ & $83(2)$ & & & \\
\hline $\mathrm{Ca}(\mathrm{Ib})$ & 1 & $1 / 3$ & $2 / 3$ & $5037(2)$ & & & \\
\hline $\mathrm{Ca} 2$ & 1 & $102(1)$ & 2605 (I) & $2430(1)$ & & & \\
\hline$P$ & $0.973(6)$ & $3979(1)$ & $3686(1)$ & $2520(1)$ & & & \\
\hline 01 & 1 & $3282(3)$ & $4840(4)$ & $2523(4)$ & & & \\
\hline 02 & 1 & $5839(4)$ & $4631(4)$ & $2279(5)$ & & & \\
\hline $03 a$ & 1 & $3254(5)$ & $2468(4)$ & $848(5)$ & & & \\
\hline $03 \mathrm{~b}$ & 1 & $3613(5)$ & $2715(5)$ & $4403(5)$ & & & \\
\hline 04 & $0.897(24)$ & 0 & 0 & $3150(12$ & & & \\
\hline \multirow[t]{2}{*}{ B } & $0.830(62)$ & 0 & 0 & $1 / 2$ & & & \\
\hline & U11 & 022 & U33 & U12 & U13 & U23 & $\mathrm{B}^{*}$ \\
\hline $\mathrm{Ca}(1 \mathrm{a})$ & $157(4)$ & 157 & $65(5)$ & 78 & 0 & 0 & 1.00 \\
\hline $\mathrm{Ca}(1 \mathrm{~b})$ & $173(4)$ & 173 & $85(5)$ & 86 & 0 & 0 & 1.13 \\
\hline $\mathrm{Ca} 2$ & $183(4)$ & $259(4)$ & $218(4)$ & $83(4)$ & $-35(3)$ & $-36(3)$ & 1.83 \\
\hline $\mathrm{P}$ & $193(5)$ & $162(4)$ & $85(3)$ & $144(4)$ & $-27(3)$ & $-21(3)$ & 0.96 \\
\hline 01 & $207(13)$ & $176(12)$ & $146(11)$ & $152(11)$ & $-7(9)$ & $O(9)$ & 1.20 \\
\hline 02 & $211(15)$ & $274(17)$ & $346(17)$ & $165(14)$ & $-17(12)$ & $-70(13)$ & 2.03 \\
\hline 03a & $576(24)$ & $200(15)$ & $200(14)$ & $238(16)$ & $-178(15)$ & $-99(12)$ & 2,41 \\
\hline o3b & $626(27)$ & $453(22)$ & $165(13)$ & $427(23)$ & $97(15)$ & $114(14)$ & 2.72 \\
\hline 04 & $286(27)$ & 286 & $458(48)$ & 143 & 0 & 0 & 2.71 \\
\hline B & $274(60)$ & 274 & $327(92)$ & 137 & 0 & 0 & 2.30 \\
\hline
\end{tabular}

Table 4. Population, positional $\left(\times 10^{4}\right)$, anisotropic thermal $\left(\times 10^{4}\right)$ and equivalent thermal parameters of the BAP, where equivalent thermal parameters $B^{*}=$ $4 / 3\left(\beta_{11} a^{2}+\beta_{22} b^{2}+\beta_{33} c^{2}+2 \beta_{12} a b \cos \gamma\right)$. 
Table 5. Interatomic distances $(\AA)$ and bond angles $\left({ }^{\circ}\right)$

$\begin{array}{llll}\mathrm{PO}_{4} & \text { tetrahedra } \\ \mathrm{P}-\mathrm{O}(1) & 1.530(4) & 0(1)-\mathrm{P}-\mathrm{O}(2) & 111.2(2) \\ \mathrm{P}-\mathrm{O}(2) & 1.532(3) & 0(1)-\mathrm{P}-\mathrm{O}(3 \mathrm{a}) & 110.2(2) \\ \mathrm{P}-\mathrm{O}(3 \mathrm{a}) & 1.529(3) & 0(1)-\mathrm{P}-\mathrm{O}(3 \mathrm{~b}) & 112.2(2) \\ \mathrm{P}-\mathrm{O}(3 \mathrm{~b}) & 1.528(4) & 0(2)-\mathrm{P}-\mathrm{O}(3 \mathrm{a}) & 108.0(2) \\ \text { mean } & 1.530 & 0(2)-\mathrm{P}-\mathrm{O}(3 \mathrm{~b}) & 106.9(2) \\ & & 0(3 a)-\mathrm{P}-0(3 \mathrm{~b}) & 107.9(2)\end{array}$

$\mathrm{BO}_{2}$ groups

B-O(4) $\quad 1.277(8)$

Ca(2) triangles

$\mathrm{Ca}(2)-\mathrm{Ca}(2) \quad 4.185(2)$

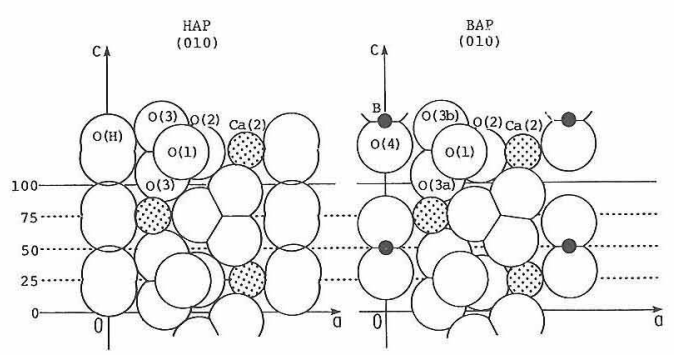

Fig. 4. The crystal structures of HAP and BAP projected on $(010)$. The $B$ atom is located at $(001 / 2)$ and $\mathrm{BO}_{2}$ groups occupies $\mathrm{OH}$ column of $\mathrm{HAP}$.

電荷バランスを考虑し，組成を $\mathrm{Ca}_{10}\left(\mathrm{PO}_{4}\right)_{6} \mathrm{~B}_{2 / 3} \mathrm{O}_{2}$ と 仮定して解析を進め, $R=5.08, R_{\mathrm{w}}=4.49 \%$ を得た。

全原子の席占有率を電荷バランスを考慮せずに変化させ ると, $\mathrm{Ca}(1 \mathrm{a}), \mathrm{P}, \mathrm{O}(4), \mathrm{B}$ の席占有率が有意に変 化した．そこでこれらの原子のみ席占有率を変化させる 亡, Ca(1 a), P, O( 4), B の席占有率はそれぞれ -3. 7, $-2.7,-10.3,+24.6 \%$ 変化して，信頼度因子も有意 に低下した $\left(R=5.00, R_{\mathrm{w}}=4.40 \%\right)$. この組成 $\mathrm{Ca}_{9.93}$ $\left(\mathrm{P}_{5.84} \mathrm{O}_{24}\right) \mathrm{B}_{0.83} \mathrm{O}_{1.79}$ は化学分析值から得られた組成 $\mathrm{Ca}_{9.64}$ $\left(\mathrm{P}_{5.73} \mathrm{~B}_{0.27} \mathrm{O}_{24}\right)\left(\mathrm{BO}_{2}\right)_{0.73}$ とほぼ一致した。表 4 に得られ た原子パラメーターを, 表 5 に原子間距離と結合角, 図 4 に結晶構造を示す.

\section{4. 考察}

$\mathrm{CaO}-\mathrm{P}_{2} \mathrm{O}_{5}-\mathrm{B}_{2} \mathrm{O}_{3}$ 系汃ら得られる $\mathrm{BAP}$ の化学組成, $\mathrm{B}$ の固溶領域, 及び $\mathrm{B}$ の結晶化学的配位は明確にされ ていない. Bauer ${ }^{9)}$ は BAP の組成を $\mathrm{Ca}_{10}\left(\mathrm{PO}_{4}\right)_{5} \mathrm{BO}_{4}$ で あると考えた. Ramamoorthy と Rockett ${ }^{10)}$ は BAPを $\mathrm{Ca}_{10}\left(\mathrm{PO}_{4}\right)_{5} \mathrm{BO}_{4}-\mathrm{Ca}_{10-7 \sigma}\left(\mathrm{PO}_{4}\right)_{6-4 \sigma} \mathrm{O}_{1-\sigma}(\delta \doteqdot 0.77)$ 系固 溶体であるとした（図 3 の破線の組成）。ここに $\mathrm{Ca}_{10}$ $\left(\mathrm{PO}_{4}\right)_{5} \mathrm{BO}_{4}$ は $\mathrm{PO}_{4}$ サイトに $\mathrm{BO}_{4}$ が存在し, $\mathrm{OH}$ サイト に空孔が形成されていると考えられている、 $\mathrm{Ca}_{10-70}$
$\left(\mathrm{PO}_{4}\right)_{6-4 \delta} \mathrm{O}_{1-\sigma}$ は $\mathrm{Ca} / \mathrm{P}$ モル比が 1.67 よりもわずかに 小さいオキシアパタイトである. Calvo とFaggiani は $\mathrm{Na}_{2} \mathrm{~B}_{4} \mathrm{O}_{7} \cdot 10 \mathrm{H}_{2} \mathrm{O}$ をフラックスとして, $\mathrm{Sr}_{3}\left(\mathrm{PO}_{4}\right)_{2}$ 又 は $\mathrm{Ca}_{3}\left(\mathrm{PO}_{4}\right)_{2}$ からアパタイト型化合物の単結晶を合成 し, 化学分析と構造解析を行った. その結果これらの結 晶は $\mathrm{OH}$ カラムに $\mathrm{BO}_{2}$ 基をもち, 組成は $\mathrm{Sr}_{9+y} \mathrm{Na}_{x}$ $\left(\mathrm{PO}_{4}\right)_{6} \mathrm{~B}_{x+2 y} \mathrm{O}_{2}, \quad \mathrm{Ca}_{9+y} \mathrm{Na}_{x}\left(\mathrm{PO}_{4}\right)_{6} \mathrm{~B}_{x+2 y} \mathrm{O}_{2}(9+y+x<$ $10, x+2 y<1, x, y>0)$ であらわせるとした.

従来の研究ではBAP の化学組成は明らかでなかっ た.これは BAP を単離するのが困難であったためと推 察される.この研究では $\mathrm{mm}$ オーダーの BAP 単結晶を 合成, 単離し, 化学分析と構造解析を行った。化学分析 の結果, BAP の組成は $\mathrm{Ca}_{10}\left(\mathrm{PO}_{4}\right)_{5} \mathrm{BO}_{4}-\mathrm{Ca}_{10-10}$ $\left(\mathrm{PO}_{4}\right)_{6-4 \delta} \mathrm{O}_{1-\delta}(\delta \fallingdotseq 0.77)$ 系固溶体(図 3 の破線)ではな $<, \mathrm{Ca}_{10}\left(\mathrm{PO}_{4}\right)_{5} \mathrm{BO}_{4}-\mathrm{Ca}_{9.5}\left(\mathrm{PO}_{4}\right)_{6} \mathrm{BO}_{2}$ 系固溶体として表 されることがわかった. $\mathrm{Ca}_{10}\left(\mathrm{PO}_{4}\right)_{5} \mathrm{BO}_{4}$ は, Bauer ${ }^{9}$ が 考えた組成と同じである。 $\mathrm{Ca}_{9.5}\left(\mathrm{PO}_{4}\right)_{6} \mathrm{BO}_{2}$ は, $\mathrm{Ca}_{9+y} \mathrm{Na}_{x}\left(\mathrm{PO}_{4}\right)_{6} \mathrm{~B}_{x+2 y} \mathrm{O}_{2}$ において $x=0, y=0.5$ に相当 する. $\mathrm{OH}$ カラムに $\mathrm{BO}_{2}$ 基が存在することが構造解析 の結果確認された。 $\mathrm{PO}_{4}$ サイトにホウ酸基が置換する ことは確認できなかった。しかし BAP のP-O原子間距 離 $(1.528 \sim 1.532 \AA)$ が $\mathrm{HAP}(1.532 \sim 1.539 \AA)^{17.18)}$ よ り有意に短いこと，及び $\mathrm{P}$ の席占有率が 1 よりさい ことはホウ酸基の置換を示唆していると思われる.

$\mathrm{BO}_{2}$ 基を有するアパタイトは Calvoと Faggiani ${ }^{5)}$ が 初めて報告した。 $\mathrm{Ca}_{9+y} \mathrm{Na}_{x}\left(\mathrm{PO}_{4}\right)_{6} \mathrm{~B}_{x+2 y} \mathrm{O}_{2}$ は空間群 $P \overline{1}$ で B-O 原子間距離は 1.23( 1 ) 1.244(18) $\mathrm{A}, \mathrm{Sr}_{9+y} \mathrm{Na}_{x}$ $\left(\mathrm{PO}_{4}\right){ }_{6} \mathrm{~B}_{x+2 y} \mathrm{O}_{2}$ は空間群 $P \overline{3}$ で $\mathrm{B}-\mathrm{O}$ 原子間距離は 1. 253(10) - 1.263(18) §である5 . また気体 $\mathrm{BO}_{2}$ 分子は 直線状対称 3 原子分子で, B-O 原子間距離 1.2653(6) $\AA^{19)}$ である. BAP の B-O 原子間距離 1.277( 8$) \AA$ はこ れらの值に一致した。 BAP の構造は $\mathrm{OH}$ カラムの欠阸 に $\mathrm{BO}_{2}$ 分子をトラップした構造と考えることができる.

通常のアパタイト (六方晶系, 空間群 $P 6_{3} / m$ ) では $Z=1 / 4,3 / 4$ に鏡面が存在し， $\mathrm{PO}_{4}$ 基と $\mathrm{Ca}(2)$ は鏡 面上に存在する。 $\mathrm{BAP}$ では $\mathrm{PO}_{4}$ 基が $c$ 軸に対して $\mathrm{P}-\mathrm{O}(1)$ 結合を軸にして約 $7^{\circ}$ 回転すること，鏡面上に 存在した $\mathrm{Ca}(2)$ が鏡面の上又は下に $0.048 \AA$ 変位する こと, $(001 / 2)$ に $\mathrm{BO}_{2}$ が存在することなどによって鏡 面の対称をやぶっていた。このため BAP は空間群 $P$ $6_{3} / m$ から $P \overline{3}$ に対称性が低下している。これらの構造 上の特徵は $\mathrm{Sr}_{9+y} \mathrm{Na}_{x}\left(\mathrm{PO}_{4}\right)_{6} \mathrm{~B}_{x+2 y} \mathrm{O}_{2}$ (空間群 $\left.P \overline{3}\right)$ と同 じである. $\mathrm{BAP} の \mathrm{Ca}(1 a), \mathrm{Ca}(1 b)$ 及び $\mathrm{O}(3 a), \mathrm{O}$ $(3 b)$ は $P 6_{3} / m$ のアパタイトでは等価である. $\mathrm{Ca}(1 b)$ は $\mathrm{Sr}_{9+y} \mathrm{Na}_{x}\left(\mathrm{PO}_{4}\right)_{6} \mathrm{~B}_{x+2 y} \mathrm{O}_{2}$ では $\mathrm{Na}$ サイトに相当する。

BAP の結晶構造と炭酸アパタイトの結晶構造を比較 するのは興味深い。炭酸アパタイト構造中で，炭酸基は $\mathrm{CO}_{3}^{2-}$ として $\mathrm{PO}_{4}$ 基又は $\mathrm{OH}$ 基を置換すると考えられて 
いるが，ESR スペクトルの結果から $\mathrm{CO}_{2}^{-}$ラジカルを 形成しているという報告 ${ }^{20)}$ もある. $\mathrm{CO}_{2}^{-}$ラジカルは $\mathrm{O}-\mathrm{C}-\mathrm{O}$ 角 $127^{\circ 21}$ のものが知られているが，炭酸アパ夕 イト中での $\mathrm{CO}_{2}^{-}$ラジカルの $\mathrm{O}-\mathrm{C}-\mathrm{O}$ 角はわかっていな い. また気体 $\mathrm{CO}_{2}$ では $\mathrm{O}-\mathrm{C}-\mathrm{O}$ 角は $180^{\circ}$ で $\mathrm{C}-\mathrm{O}$ 原子間 距離は $1.1600 \AA^{22)}$ である. アパタイト構造中にこのよ うな $\mathrm{BO}_{2}$ 基が存在するならば, $\mathrm{B}$ と $\mathrm{C}$ の原子半径の類 似性から考えて, $\mathrm{BO}_{2}$ 基と同様, 直線的な $\mathrm{O}-\mathrm{C}-\mathrm{O}$ 基と して OH カラムに存在するのではないかと考えられる.

\section{5. まとめ}

(1) $\mathrm{CaO}-\mathrm{P}_{2} \mathrm{O}_{5}-\mathrm{B}_{2} \mathrm{O}_{3}$ 系からフラックス徐冷法でホ ウ素含有アパタイト (BAP) 単結晶を合成し, 化学分 析と結晶構造解析を行った。

(2) 最大直径 $0.3 \mathrm{~mm}$, 長さ $11 \mathrm{~mm}$ の BAP が得ら れた.

(3) BAP の化学組成は $\mathrm{Ca}_{10}\left(\mathrm{PO}_{4}\right){ }_{5} \mathrm{BO}_{4}-\mathrm{Ca}_{9.5}$ $\left(\mathrm{PO}_{4}\right)_{6} \mathrm{BO}_{2}$ 系固溶体として表される.

（4）BAP は三方晶系に属し, 空間群 $P \overline{3}$, 格子定 数 $a=9.456(1), c=6.905(1) \AA ， Z=1$ である. その 構造は水酸アパタイトに良く似ているが, $\mathrm{OH}$ カラム中 に $\mathrm{B}$ 原子が $\mathrm{BO}_{2}$ 基として存在する.

\section{文献}

1) J. S. Prener, J. Electrochem. Soc., 114, 77-83 (1967).

2) K. Sudarsanan and R.A. Young, Acta Cryst., B30, 1381-86 (1974).

3) K. Sudarsanan, R. A. Young and A. J. C. Wilson, Acta
Cryst., B33, 3136-42 (1977).

4) K. Sudarsanan, R.A. Young and J. Donnay, Acta Cryst., B29, 808-14 (1973).

5) C. Calvo and R.Faggiani, J.C.S. Chem. Comm., 714-15 (1974).

6) C. Calvo, R. Faggiani and N. Krishnamachari, Acta Cryst., B31, 188-92 (1975).

7) D. M. Roy, Mater. Res. Bull., 6, 1337-40 (1971).

8) W. Eysel and D. M. Roy, J. Crystal Growth, 20, 245-50 (1973).

9) H. Bauer, Angew. Chem., 71, 374 (1959).

10) P. Ramamoorthy and T.J. Rockett, J. Am. Ceram. Soc., 57, 501-02 (1974).

11）日本分析化学会編, 分析化学便覧改訂 3 版, 丸善 (1958) p. 56 .

12) J. Murphy and J. P. Riley, Anal. Chim. Acta, 27, 31-36 (1962).

13) N.H. Furman Ed., "Standard Methods of Chemical Analysis, 6th ed. Vol.1”, D. Van Nostrand Company, Inc. (1962) p. 217.

14) International Tables for X-ray Crystallography, Vol. 4 (1974).

15) 桜井敏雄編, UNICS (Universal Crystallographic Computation Program System), 日本結晶学会 (1967).

16) S. Coppens and W.C. Hamilton, Acta Cryst., A26, 71-83 (1970).

17) M. I. Kay, R. A. Young and A.S. Posner, Nature, 204, 1050-52 (1964).

18) K. Sudarsanan and R.A. Young, Acta Cryst., B25, 1534-43 (1969).

19) J.W.C. Johns, Can. J. Phys., 39, 1738-68 (1961).

20) Y. Doi, Y. Moriwaki, T. Aoba, M. Okazaki and J. Takahashi, J. Osaka Univ. Dent. Sch., 21, 75-85 (1981).

21) J. E. Bennett, B. Mile and A. Thomas, Trans. Faraday Soc., 63, 262-73 (1967).

22）日本化学会編, “化学便覧改訂 2 版, 基礎編 II”, 丸善(1975) p. 1381. 